\title{
Article
}

\author{
망간단괴 집광기 주위 해수 유동교란 수치해석 \\ 임성진 ${ }^{1} \cdot$ 채용배 $^{1} \cdot$ 정신택 ${ }^{2} \cdot$ 조홍연 ${ }^{3} \cdot$ 이상호 $^{{ }^{*}}$ \\ 1 원광대학교 공과대학 기계자동차공학부 \\ 2원광대학교 공과대학 토목환경공학과 \\ (570-749) 전라북도 익산시 익산대로 460 \\ 3한국해양과학기술원 연안공학연구본부 \\ (426-744) 경기도 안산시 상록구 해안로 787
}

\section{Numerical Analysis of Deep Seawater Flow Disturbance Characteristics Near the Manganese Nodule Mining Device}

\author{
Sung-Jin Lim ${ }^{1}$, Yong-Bae Chae ${ }^{1}$, Shin-Taek Jeong ${ }^{2}$, Hong-Yeon $\mathrm{Cho}^{3}$, and Sang-Ho Lee ${ }^{{ }^{*}}$ \\ ${ }^{1}$ Division of Mechanical \& Automotive Engineering, College of Engineering, Wonkwang University \\ ${ }^{2}$ Department of Civil and Environmental Engineering, College of Engineering, Wonkwang University \\ Iksan 570-749, Korea \\ ${ }^{3}$ Coastal \& Environmental Engineering Division, KIOST
}

Ansan 426-744, Korea

\begin{abstract}
Seawater flow characteristics around a manganese nodule mining device in deep sea were analyzed through numerical investigation. The mining device influences the seawater flow field with complicated velocity distributions, and they are largely dependent on the seawater flow speed, device moving speed, and injection velocity from the collecting part. The flow velocity and turbulent kinetic energy distributions are compared at several positions from the device rear, side, and top, and it is possible to predict the distance from which the mining device affects the seawater flow field through the variation of turbulent kinetic energy. With the operation of the collecting device the turbulent kinetic energy remarkably increases, and it gradually decreases along the seawater flow direction. Turbulent kinetic energy behind the mining system increases with the seawater flow velocity. The transient behavior of nodule particles, which are not collected, is also predicted. This study will be helpful in creating an optimal design for a manganese nodule collecting device that can operate efficiently and which is eco-friendly.
\end{abstract}

Key words : manganese nodule, mining device, numerical analysis, deep sea, flow characteristics

\section{1. 서 론}

최근에 이르러 많은 육상광물의 고갈 문제가 심각하게 대두됨에 따라 이를 대체할 수 있는 해양광물자원에 대한

*Corresponding author. E-mail : lsheagle@wku.ac.kr
관심이 갈수록 급증하고 있다. 여러 해양광물자원 중 수심 $4000 \sim 6000 \mathrm{~m}$ 의 심해저면에 다량 부존되어 있는 망간단 괴는 대표적인 심해저 광물자원이다. 망간단괴는 1000년 에 0.01 1 mm 정도가 퇴적되고 망간, 니켈, 구리, 코발트, 희토류 등 희유금속이 다량 함유되어 있어 그 가치가 매 우 높으며 하와이 동남쪽 약 $2,000 \mathrm{~km}$ 지점에 있는 클라 
리온-클리퍼톤(Clarion-Clipperton, C-C) 해역에 주로 부존 되어 있는 것으로 알려져 있다(LRET Collegium 2012). 현재 우리나라는 이 지역의 7 만 $5000 \mathrm{~km}^{2}$ 에 대한 광구권 을 확보한 상태이고 이 지역에는 약 5억 6000만 톤의 망 간단괴가 부존되어 있는 것으로 알려져 있으며 이는 연간 300 만 톤씩 100 년 이상 채광할 수 있는 양이다. 망간 단괴 채광을 위해 수심 4000 6000 m의 심해에 집광기를 투입 시켜 운행하기 위해 장치기술에 대한 개발이 지속적으로 이루어지고 있으며 국내·외에서 심해저에 부존되어 있는 망간단괴 채광방법에 대한 연구가 활발하게 이루어지고 있다. 국내에서는 현재 약 $1,400 \mathrm{~m}$ 수심의 심해에서 시범 주행에 성공한 상태이며 지속적인 연구개발 중에 있다. 채 광시스템은 크게 집광장치와 양광장치로 구분되어 있는데 집광장치는 해저면에 부존되어 있는 망간단괴를 채집하는 장치이고 양광장치는 집광장치를 통해 채집된 망간단괴를 해상으로 끌어올리는 장치이다(Lee et al. 2009). 망간단괴 집광기에 관련된 기존의 연구를 살펴보면 최 등 (1998)은 심해저 망간단괴 집광기 채집장치의 설계평가에 대한 연 구를 수행하였고, 조 등 (2012)은 심해 잡음인자를 고려한 망간단괴 시험집광기 주행장치의 다구치 강건설계에 대한 연구를 수행하였다. 이 등 (2013)은 코안다 효과를 이용한 심해저 망간단괴 유체식 채집장치 최적설계에 대한 연구 를 수행하였다. 또한 최 등 (2010)은 심해저 망간단괴 시 험집광기의 근해역 집광성능에 대한 분석을 수행하였고 김 등 (2010)은 심해저 광물자원 채광시스템의 통합거동 에 대해 해석하였다. 이처럼 집광기와 관련된 장치 설계 및 채광성능 분석 등에 대한 연구는 활발하게 이루어지 고 있으나 심해의 해수유동장 분석에 대한 연구는 매우 부족한 실정이다. 해수유동장 특성은 장치의 성능뿐만 아니라 집광기 주변의 심해저 생태계에도 큰 영향을 미 치는 중요한 부분인 만큼 체계적인 분석이 절대적으로 필요한 것으로 판단된다. 특히 심해저에서는 해수의 유 속이 매우 느리고 외부 장치의 출입이 거의 없는 상태이 기 때문에 망간단괴 채광을 위해 집광기가 투입되어 운 행하게 될 경우 주변 해수유동의 변화로 인해 심해저 생 물들에 적지 않은 영향을 미칠 가능성이 매우 높다고 추 정된다. 따라서 본 연구에서는 CFD 해석기법을 통해 심 해저의 망간단괴 집광기 운행 중 주변에서 발생하는 유 속분포 및 난류운동에너지를 포함한 유동장 특성에 대한 분석을 수행하였다(Rinoshika and Watanabe 2010; Aljure et al. 2014). 이를 통해 집광기의 작동과 관련된 기초적 인 해수유동장 특성데이터를 확립하고자 한다. 또한 심 해저에서 집광기 운행으로 인해 발생되는 난류운동에너 지 분포가 변화하는 영역에 대한 예측을 통해 주변 해수 유동에 미치는 영향을 파악하는 데 기여할 수 있을 것으 로 기대된다.

\section{2. 전산 해석}

\section{지배방정식}

본 연구에서는 망간단괴 집광기 주변의 해수유동장 분 석을 위해 해수의 영역, 밀도, 유속, 점도 및 집광기의 크 기 등을 고려하여 난류유동으로 설정하였으며 일반적인 RNG $k-\varepsilon$ 난류모델을 이용하였다. 망간단괴입자의 거동 이 발생하는 집광기 작동조건에 대해서는 정상상태의 해 수유동장에 대한 해석 결과를 초기조건으로 설정하여 시 간에 따른 비정상상태에 대한 해석을 수행하였다. 이와 관 련한 지배방정식들은 다음과 같다(Kim and Lee 2013).

연속방정식 :

$\frac{\partial \rho}{\partial t}+\frac{\partial}{\partial x_{i}}\left(\rho u_{i}\right)=0$

운동량방정식 :

$\frac{\partial}{\partial t}\left(\rho u_{i}\right)+\frac{\partial}{\partial x_{j}}\left(\rho u_{i} u_{j}\right)=-\frac{\partial p}{\partial x_{j}}+\frac{\partial}{\partial x_{j}}\left(\tau_{i j}+\tau_{i j}^{R}\right)+\rho g_{i}$

난류운동에너지 방정식:

$$
\begin{aligned}
& \frac{\partial}{\partial t}\left(\rho u_{i}\right)+\frac{\partial}{\partial x_{i}}\left(\rho u_{i} k\right)=\frac{\partial}{\partial x_{i}}\left[\left(\alpha_{k} \mu_{e f f}\right) \frac{\partial k}{\partial x_{i}}\right]+G_{k}+G_{b} \\
& \quad-\rho_{\varepsilon}-Y_{M}+S_{k}
\end{aligned}
$$

소산율 방정식:

$$
\begin{aligned}
& \frac{\partial}{\partial t}(\rho \varepsilon)+\frac{\partial}{\partial x_{i}}\left(\rho u_{i} \varepsilon\right)=\frac{\partial}{\partial x_{i}}\left[\left(\alpha_{\varepsilon} \mu_{e f f}\right) \frac{\partial \varepsilon}{\partial x_{i}}\right]+C_{1} \frac{\varepsilon}{k}\left(G_{k}+C_{3 \varepsilon} G_{b}\right) \\
& -C_{2 \varepsilon} \rho \frac{\varepsilon^{2}}{k}-R_{\varepsilon}+S_{\varepsilon}
\end{aligned}
$$

전단응력 및 난류점성계수 방정식:

$$
\begin{aligned}
\tau_{i j} & =\mu\left(\frac{\partial u_{i}}{\partial x_{j}}+\frac{\partial u_{j}}{\partial x_{i}}-\frac{2}{3} \delta_{i j} \frac{\partial u_{k}}{\partial x_{k}}\right) \\
\tau_{i j}^{R} & =\mu_{t}\left(\frac{\partial u_{i}}{\partial x_{j}}+\frac{\partial u_{j}}{\partial x_{i}}-\frac{2}{3} \delta_{i j} \frac{\partial u_{k}}{\partial x_{k}}\right)-\frac{2}{3} \rho k \delta_{i j} \\
\mu_{t} & =\rho C_{\mu} \frac{k^{2}}{\varepsilon}
\end{aligned}
$$

\section{전산 해석 모델}

Fig. 1은 망간단괴 집광기 주변의 해수유동장 분석을 위 한 전산해석용 $3 \mathrm{D}$ 캐드 모델을 나타낸 그림이다. 집광기 운행 시 해수유동에 영향을 주는 주요 인자는 해수유속, 


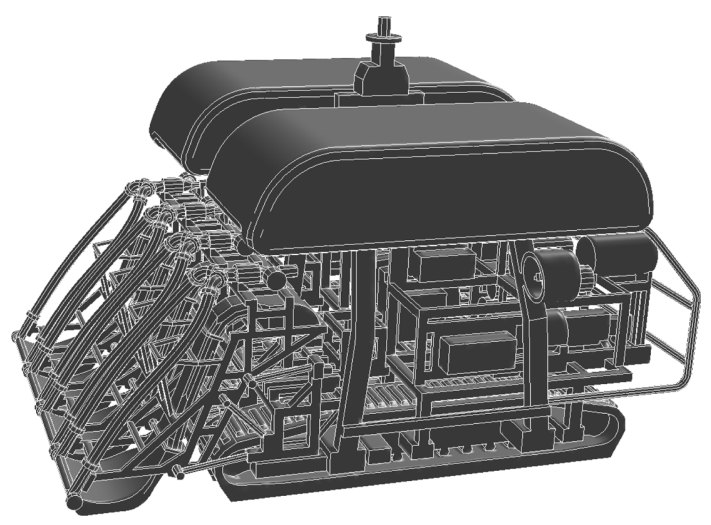

Fig. 1. Mining device geometry

집광기 이동속도, 그리고 채집장치의 작동 유/무 등 여러 가지가 있으며 특히 중요한 영향을 미치는 것은 집광기의 형상이다(Byun et al. 2014). 집광기의 전체적인 크기는 각각 폭 $5.3 \mathrm{~m}$, 길이 $6.6 \mathrm{~m}$, 그리고 높이 $4.5 \mathrm{~m}$ 정도이고 복잡한 형상과 함께 많은 부품으로 구성되어 있기 때문에 유동 특성 및 전산해석 결과의 수렴성을 고려하여 유동에 영향을 미치지 않는 부품에 대해 부분적인 단순화 작업을 거쳐 전산해석용 모델을 완성하였다. 집광기 전방 하단부 에는 Fig. 2와 같이 망간단괴 채집을 위한 제트류 분사장 치와 망간단괴 흡입장치로 구성된 채집장치 시스템이 있 으며 제트류 분사구와 망간단괴 흡입구는 각각 16 개와 4개로 구성되어 있다. Fig. 3 은 집광기 주변의 해수유동 분석을 위한 해석영역을 집광기를 중심으로 단면을 잘라 나타낸 것이다. 전체적인 해석영역의 크기는 집광기 앞쪽 과 뒤쪽은 집광기 길이의 3 배, 옆쪽은 집광기 폭의 1 배 그 리고 위쪽은 집광기 높이의 2 배 정도로 각각 설정하였으 며 집광기 전방에 해수가 유입되는 입구와 후방으로는 출 구가 형성되어 있다. 또한 집광기의 중심 하단부가 전체 도메인 좌표의 중심으로 설정되어 있다. Fig. 4는 전산해
석용 3D 캐드 모델에 대하여 상용 프로그램(Hypermesh) 을 이용하여 전체적인 격자 생성작업을 수행한 것이다. 해 수유동 특성을 고려하여 집광기 주변은 격자 밀도를 높여 작업하였으며 집광기 표면, 해석영역 입/출구, 채집장치의 제트류 분사구 및 망간단괴 흡입부, 바닥 등 면에 대해서 는 삼각형 형태의 격자를 적용시켰고 해수 영역에 대해서 는 사면체 형태의 격자로 작업하였다. 이때 생성된 총 격

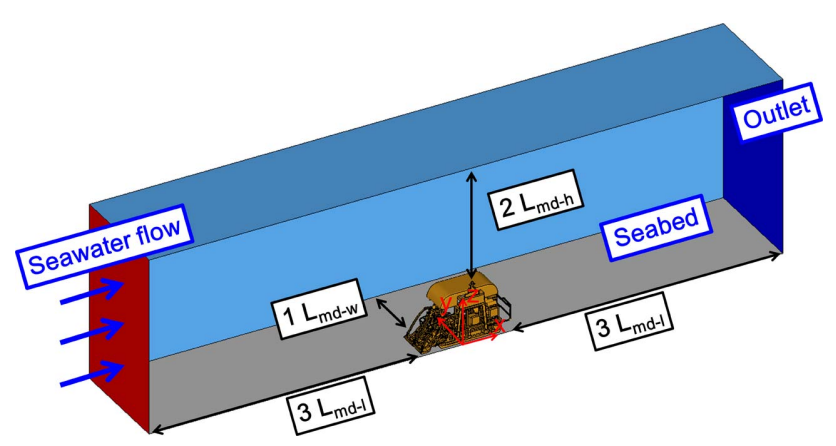

Fig. 3. Domain for numerical analysis

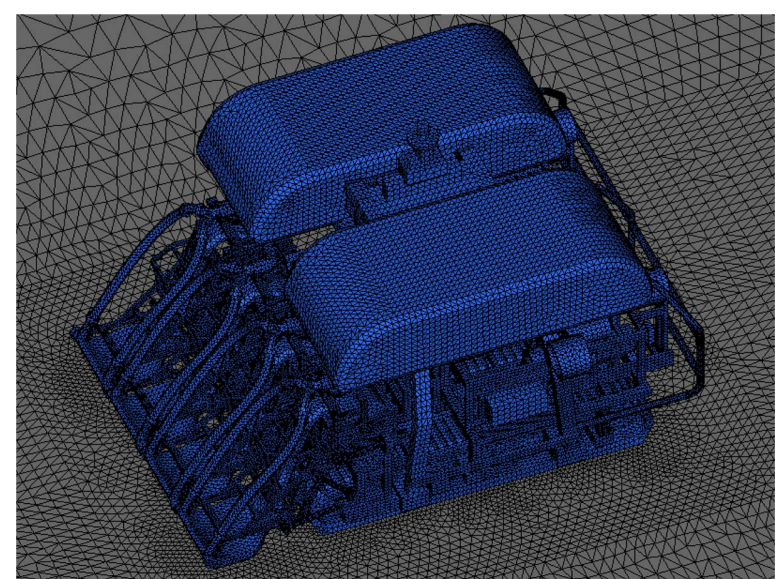

Fig. 4. Mesh generation around the mining device

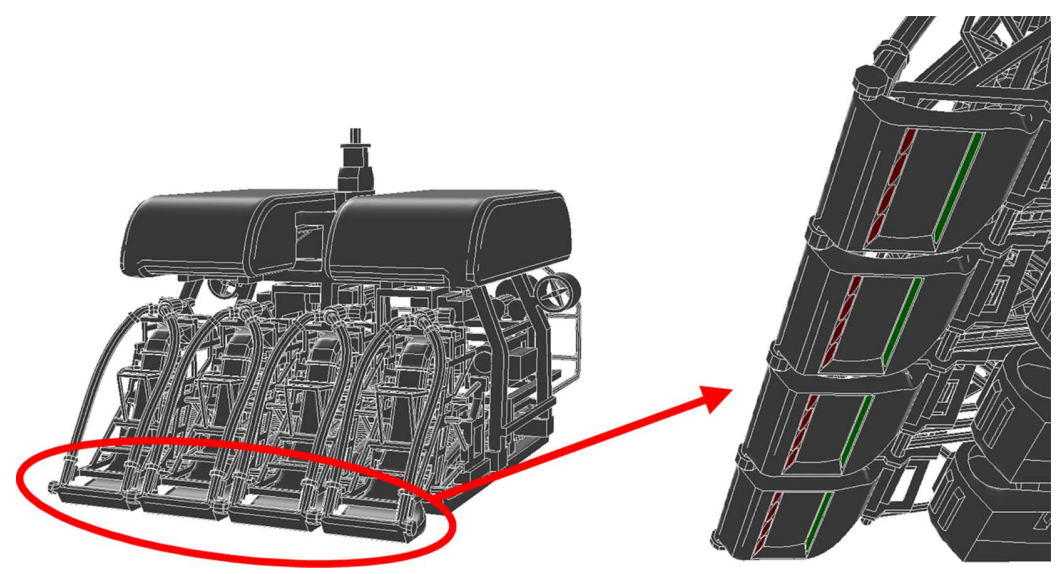

Fig. 2. Configuration of the collecting device 
자 수는 약 300 만개 정도이다. 본 연구에서는 집광기 주변 의 해수유동장 분석을 위해 상용 전산해석 프로그램인 Ansys fluent를 이용하였다. 여기서는 일반적인 유한체적 법 (Finite volume method)을 적용하고 격자경계를 출입 하는 유동에 대해서는 2차 풍상차분법(2nd Upwind Scheme)을 사용한다.

\section{해수 물성치 및 경계조건 설정}

심해 환경을 고려하여 해수 물성치 중 밀도와 점도를 각각 $\rho_{s}=1029 \mathrm{~kg} / \mathrm{m}^{3}, \mu_{s}=1.08 \times 10^{-3} \mathrm{~Pa} \cdot \mathrm{s}$ 로 설정하였다. 또한 해수유동이 약한 심해 환경을 고려하여 해수유속 $V_{s}=0.1 \mathrm{~m} / \mathrm{s}$ 로 가정하였고 유동장 내 집광기가 다양한 속 도로 이동하는 경우에 대한 해석을 수행하였다. 집광기의 이동속도 $V_{m}=0.5 \sim 3 \mathrm{~m} / \mathrm{s}$ 로 가정하였고, 해수유속 $V_{s}$ 와 집광기 이동속도 $V_{m}$ 을 고려하여 집광기 전방에 위치한 해 석영역 입구로부터 $V_{s}+V_{m}=0.6 \sim 3.1 \mathrm{~m} / \mathrm{s}$ 의 해수유동이 발생하도록 입구 조건을 설정하였다. 또한 완전 발달된 유 속분포와 함께 입구의 난류강도를 $10 \%$ 로 설정하였고 집 광기의 높이 $L_{m d-h}$ 를 특성길이로 적용하였다. 집광기 후방 의 하류부분에 대해서는 일반적인 출구 조건을 적용하였 다. 그리고 집광기의 채집장치가 작동하는 경우 제트류 분

Table 1. Operating conditions with main variables

\begin{tabular}{ccccc}
\hline Case & $\boldsymbol{V}_{\boldsymbol{m}} / \boldsymbol{V}_{\boldsymbol{s}}$ & $\boldsymbol{V}_{\boldsymbol{j}} / \boldsymbol{V}_{\boldsymbol{s}}$ & Particles & Time \\
\hline 1 & $5 \sim 30$ & $4.5 \sim 72$ & $\mathrm{X}$ & Steady \\
2 & 5 & 18 & $\mathrm{O}$ & Unsteady \\
\hline
\end{tabular}

사구로부터의 분사되는 유속 $V_{j}$ 가 해수유동 미치는 영향 을 분석하기 위해 $V_{j}=0.45 \sim 7.2 \mathrm{~m} / \mathrm{s}$ 로 분사되는 조건으로 설정하였다. 또한 채집장치의 작동 유/무에 따른 해수유동 장 특성변화를 분석하기 위해 채집장치의 분사장치로부터 제트류가 분사되는 경우와 분사되지 않는 경우를 비교하 였다. 집광기 운행 시 해저면에 망간단괴가 있는 경우와 없는 경우의 해수유동 변화를 분석하기 위해 망간단괴를 밀도와 크기가 각각 $\rho_{m n}=2100 \mathrm{~kg} / \mathrm{m}^{3}, D_{m n}=3.5 \sim 5.5 \mathrm{~cm}$ 인 구형태의 입자로 가정하였다(Yoon et al. 2009). 해석을 위한 경계조건에 적용된 여러 가지 변수에 따른 집광기 작동 조건들을 Table 1에 표시하였다.

\section{3. 결과 및 고찰}

\section{집광기 주변의 해수유동장 특성}

Fig. 5의 (a), (b)는 각각 집광기의 위와 옆에서 본 속도 벡터 분포를 나타낸 것이다. 집광기 앞쪽에서는 속도의 변 화가 크지 않지만 집광기를 지나 뒤쪽으로 갈수록 집광기 의 형상 및 이동속도에 의해 해수 흐름의 방해를 받게 되 면서 유동교란이 발생하고 집광기 뒤쪽에서는 와류현상이 발생하는 것을 볼 수 있다. 이러한 특성은 Fig. 6의 집광기 주변의 유선분포를 통해 확인 할 수 있다. 일정하게 흐르 던 해수는 집광기 위쪽을 지나면서 유동박리 현상이 나타 나며 박리된 경계층은 와류를 형성하게 되어 후류영역에 서는 유선의 형태가 복잡하게 형성된다. Fig. 7 9는 집광 기의 주변 단면에 대해 속도크기분포를 나타낸 것이다. 여

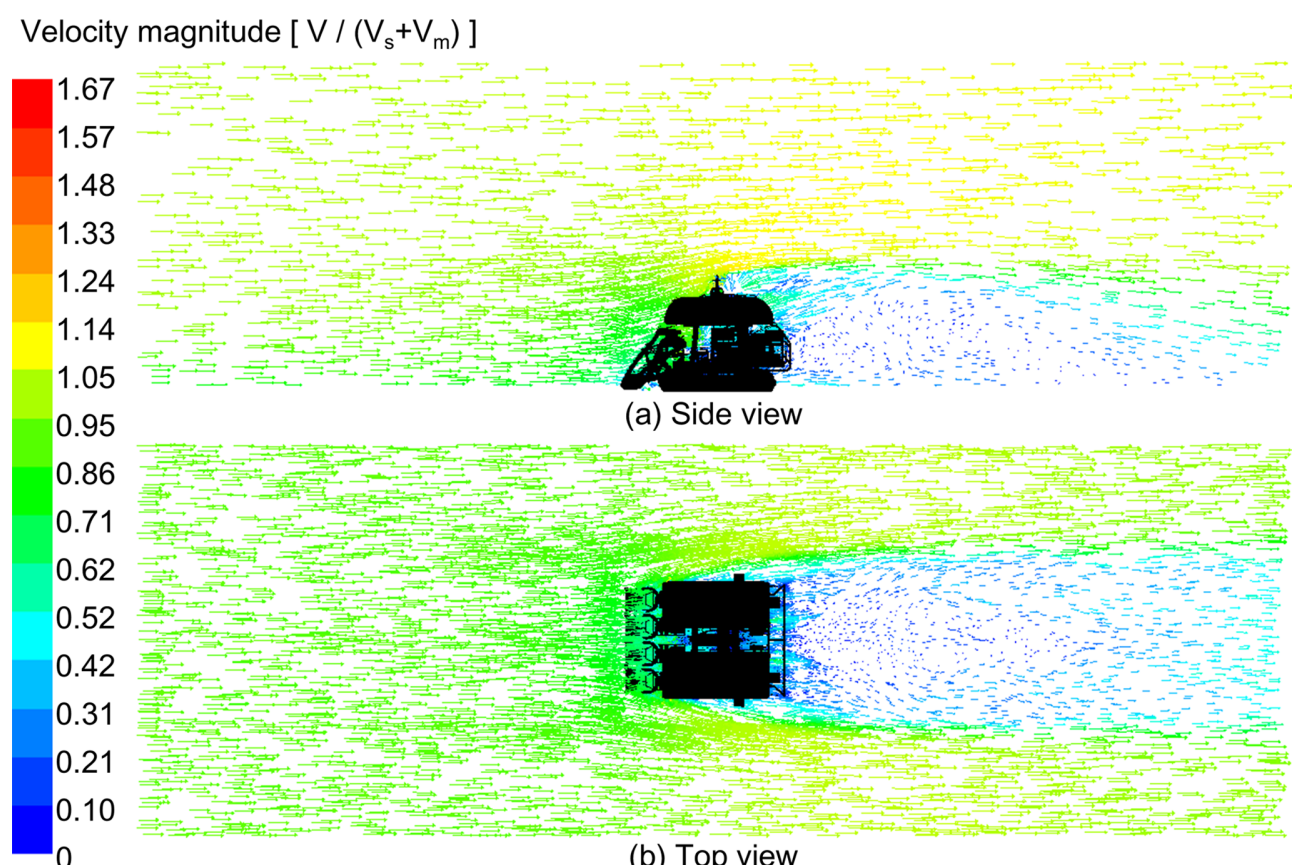

(b) Top view

Fig. 5. Velocity vectors around the mining device 


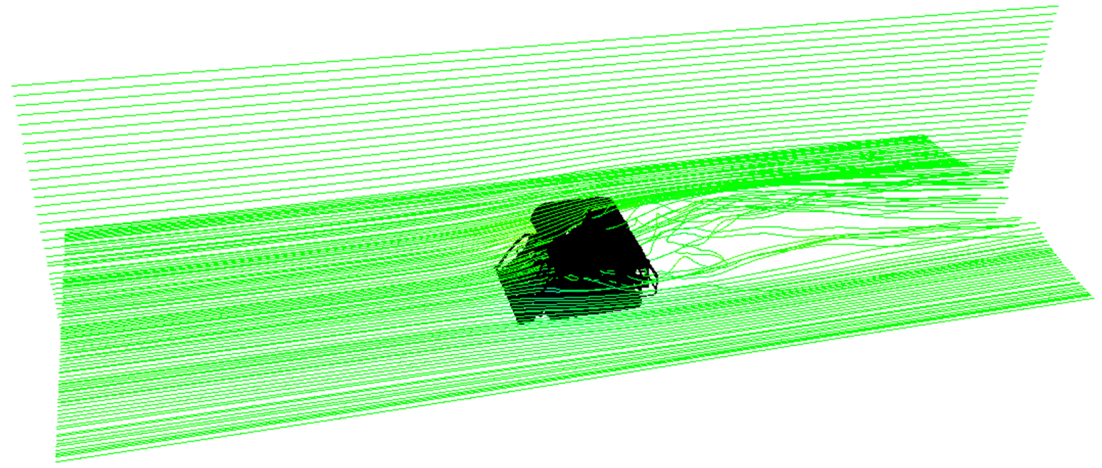

Fig. 6. Streamlines distribution around the mining device

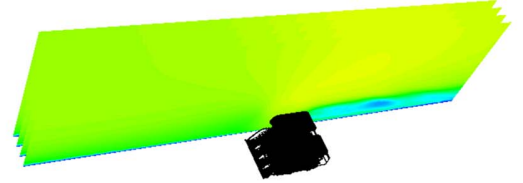

Velocity magnitude $\left[\mathrm{V} /\left(\mathrm{V}_{\mathrm{s}}+\mathrm{V}_{\mathrm{m}}\right)\right]$

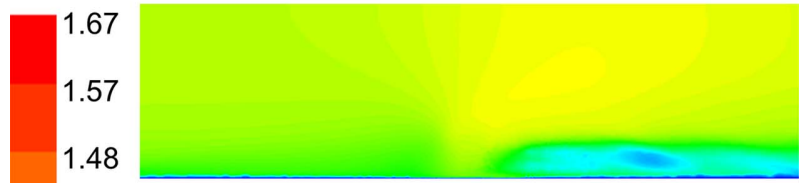

(a) $y / L_{m d-w}=0.1$

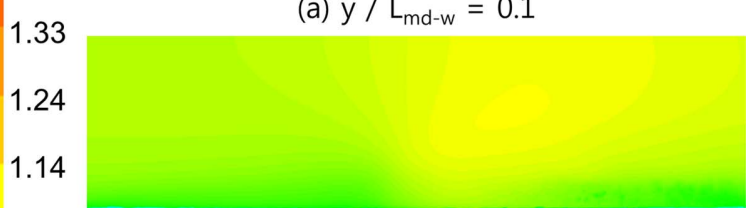

$1.05 \quad$ (b) $y / L_{m d-w}=0.3$

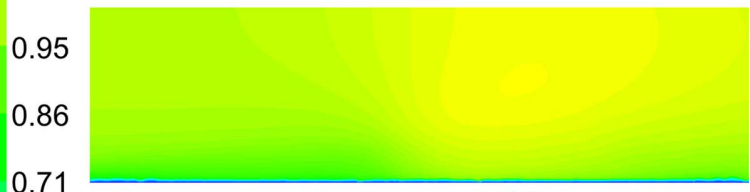

(c) $y / L_{m d-w}=0.5$

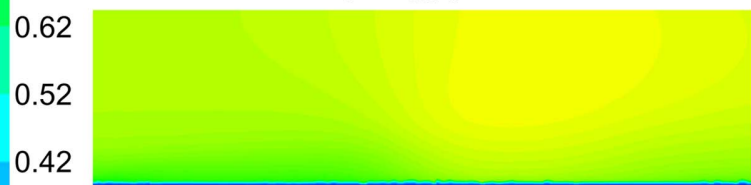

(d) $y / L_{m d-w}=0.7$

0.31

0.21

0.10

0

(e) y $/ L_{m d-w}=0.9$

Fig. 7. Flow velocity magnitude contour variation at the side of the mining device for $V_{m} / V_{s}=20, V_{j} / V_{s}=18$

기서 $L_{m d-w}, L_{m d-h}, L_{m d-l}$ 는 각각 집광기의 폭, 높이, 길이를 나타낸 것이다. 해수유동 속도는 집광기의 거동에 의해 전
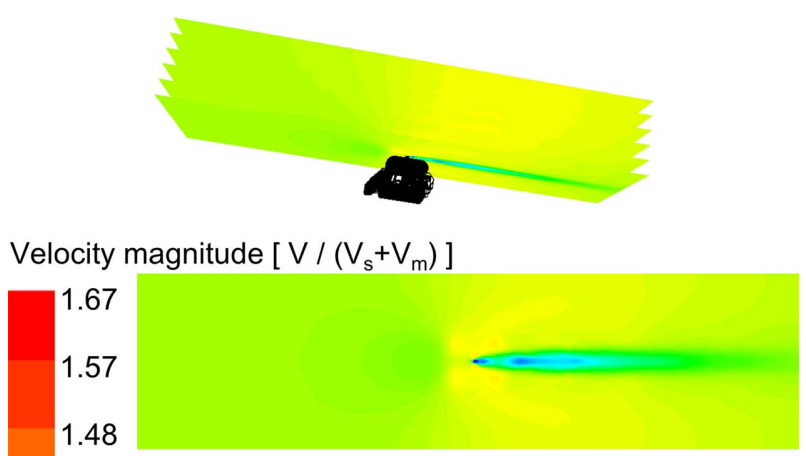

(a) $z / L_{m d-h}=0.11$

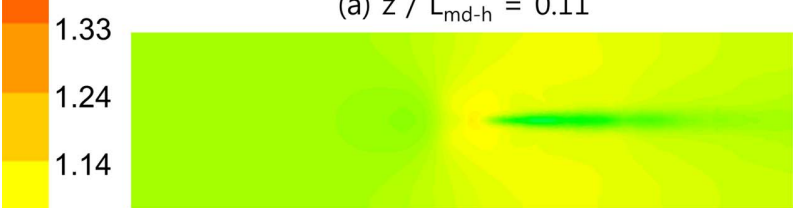

(b) $z / L_{m d-h}=0.22$

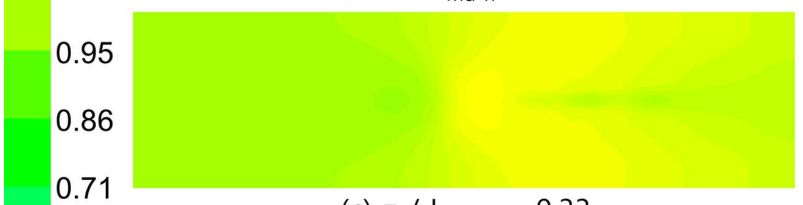

(c) $z / L_{m d-h}=0.33$

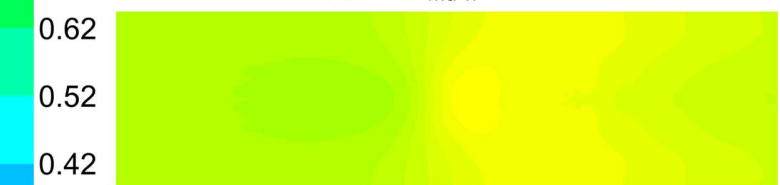

(d) $z / L_{m d-h}=0.44$

(e) $z / L_{m d-h}=0.56$

Fig. 8. Flow velocity magnitude contour variation above the mining device for $V_{m} / V_{s}=20, V_{j} / V_{s}=18$

방에서 약간 감소하다가 집광기의 윗부분을 지나면서 유 속이 점차 빨라지게 된다. 특히 집광기 후방에서는 유동박 


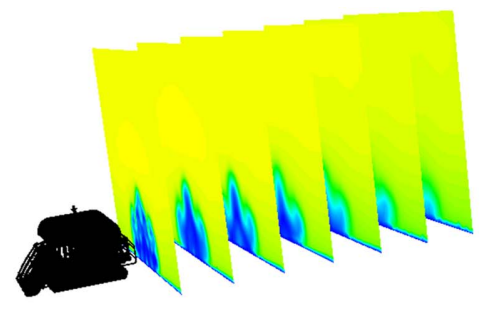

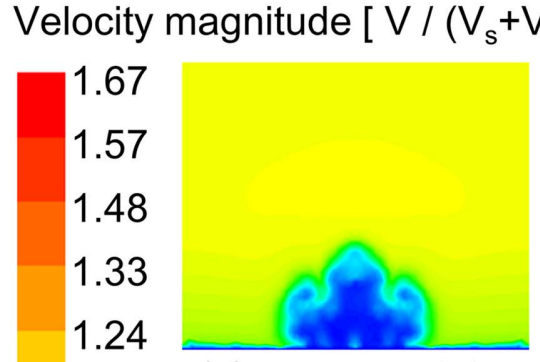

1.14

(a) $x / L_{\text {md-I }}=0.3$

1.05
0.95
0.86
0.71
0.62
0.52
0.42
0.31
0.21
0.10
0 (d) $x / L_{m d-I}=1.2$

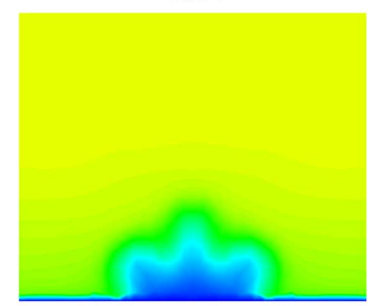

(g) $x / L_{\text {md-I }}=2.1$

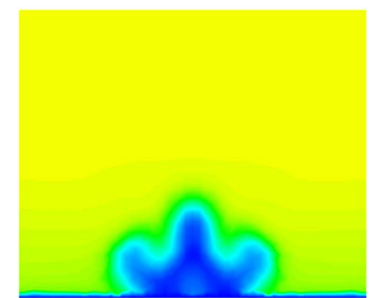

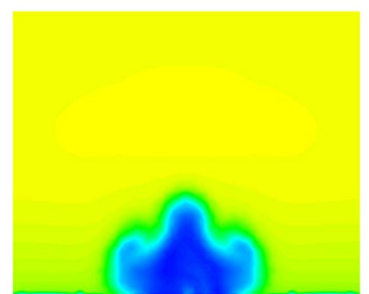

(b) $x / L_{\text {md-I }}=0.6$

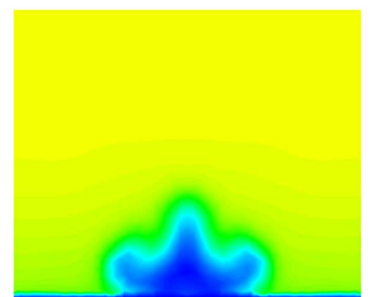

(e) $x / L_{\text {md-I }}=1.5$

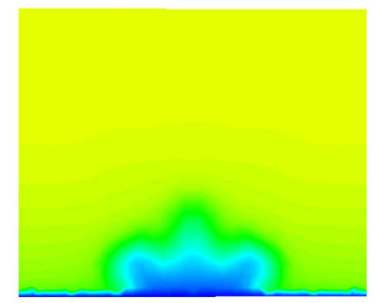

(h) $x / L_{m d-l}=2.4$

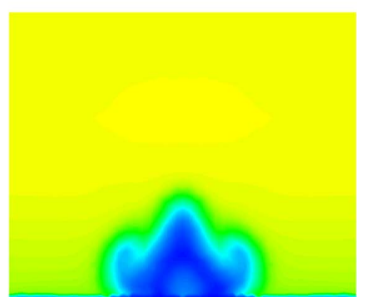

(c) $x / L_{m d-I}=0.9$

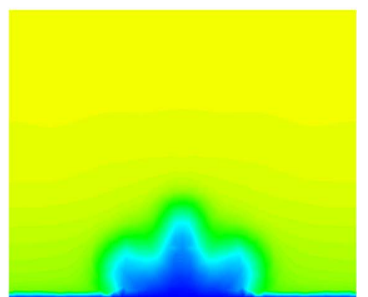

(f) $x / L_{\text {md-I }}=1.8$

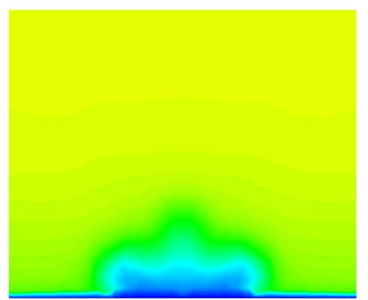

(i) $\mathrm{x} / \mathrm{L}_{\mathrm{md}-\mathrm{I}}=2.7$

Fig. 9. Flow velocity magnitude contour variation behind the mining device for $V_{m} / V_{s}=20, V_{j} / V_{s}=18$

리에 의한 와류현상이 발생하여 유속이 $0 \mathrm{~m} / \mathrm{s}$ 에 가까운 영역이 나타나며 다른 부분에 비해 해수유동 속도가 매우 느린 것을 볼 수 있다. 이러한 영향은 후방으로 갈수록 점 차 감소하다가 주변 해수유속에 가까워지게 되고 집광기 옆쪽과 위쪽에서는 뒤쪽에 비해서 집광기에 의한 해수유 속의 변화가 적은 것을 볼 수 있다.

\section{집광기 주변의 난류운동에너지 변화}

Fig. 10 의 (a) (c)는 집광기의 이동속도에 따른 집광기 주변에서의 난류운동에너지의 변화를 나타낸 것이다. (a) 는 집광기 뒤쪽에서의 평균 난류운동에너지를 나타낸 것 인데, 와류 현상에 의한 복잡한 유동이 형성되기 때문에 다른 영역에 비해 높은 난류운동에너지가 발생하고 집광
기에 의한 영향을 받지 않는 영역의 난류운동에너지에 비 해 최대 약 8 배 정도 높게 발생한다. 또한 난류운동에너지 는 집광기로부터 멀어질수록 점차 감소하는 것을 볼 수 있으며 집광기의 이동속도가 증가함에 따라 평균 난류운 동에너지의 감소율은 커진다. $V_{m} / V_{s}$ 가 5 만큼 증가할 때 집 광기가 영향을 미치는 범위 내에서의 평균 난류운동에너 지는 약 $4 \%$ 정도 증가하는 것을 볼 수 있다. (b)는 집광기 위쪽에서의 난류운동에너지 변화를 나타낸 것이다. 위쪽 에서의 난류운동에너지는 집광기에 의한 영향을 받지 않 는 영역의 난류운동에너지에 비해 최대 약 1.4 배 정도 높 게 나타난다. 이후 $L_{m d-h}$ 의 약 0.4 배 정도 떨어진 영역까지 급격하게 감소하고 이후 서서히 감소하여 약 1.8 배 떨어 진 영역에서부터는 집광기에 의한 영향을 받지 않는다는 

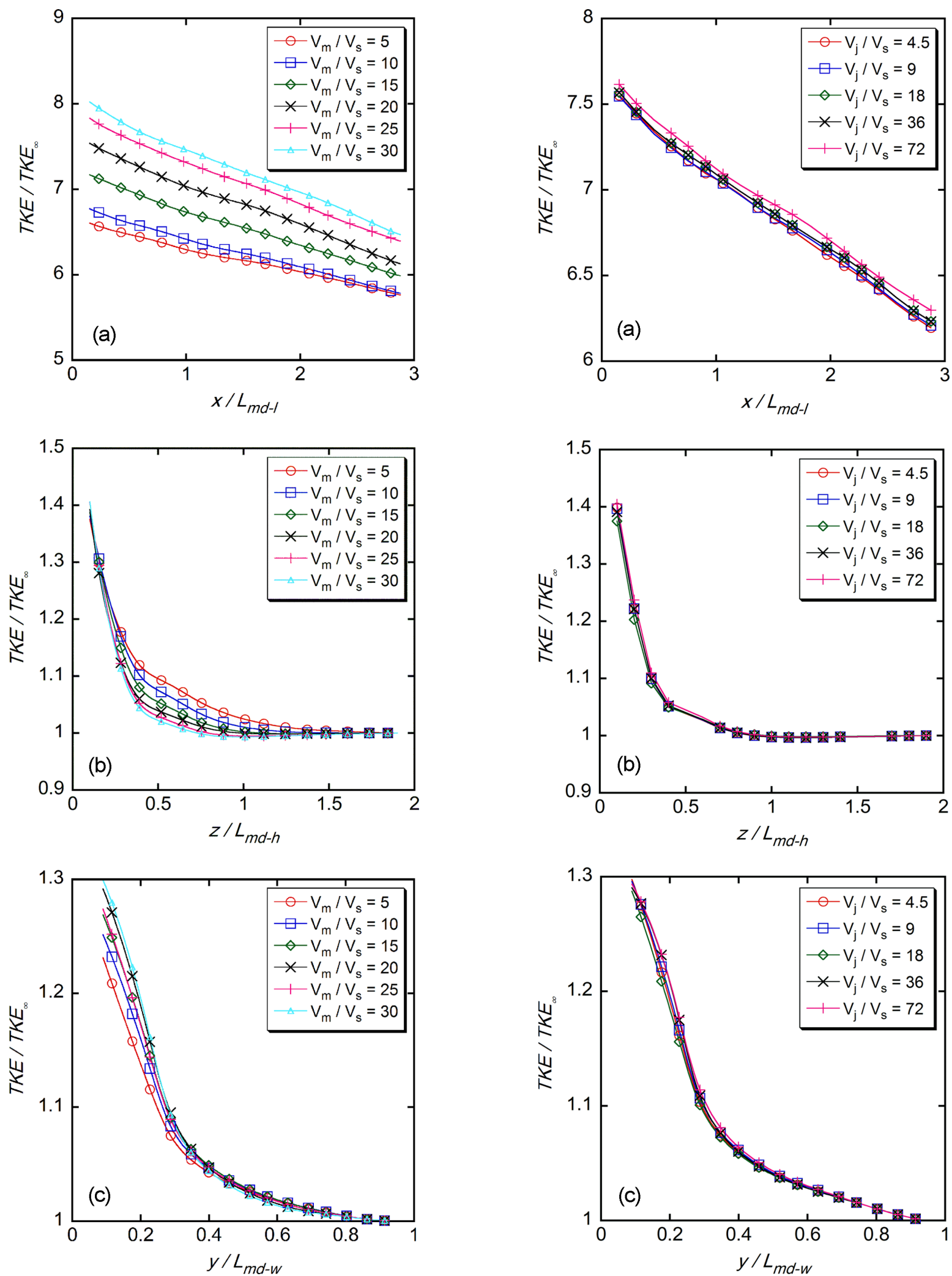

Fig. 10. Averaged turbulent kinetic energy variation for $V_{j} / V_{s}=18$. (a) Behind the mining device, (b) Above the mining device, (c) Side of the mining device

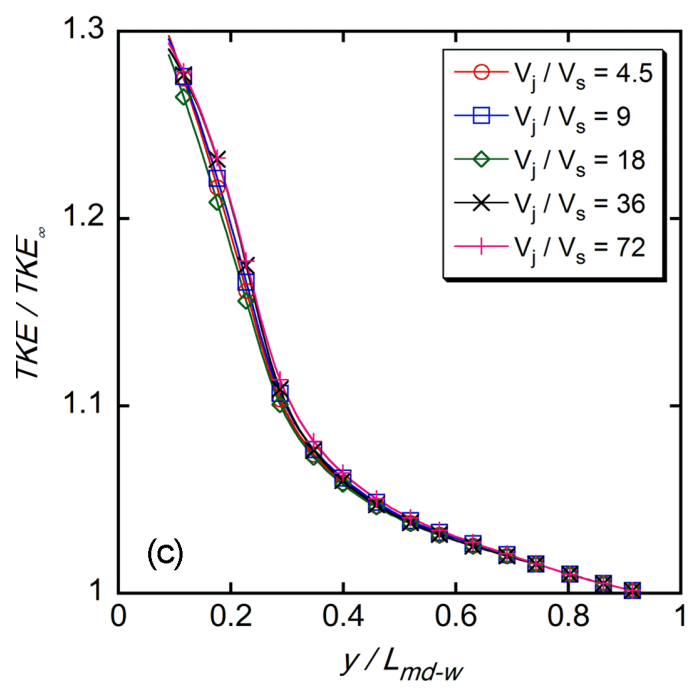

Fig. 11. Averaged turbulent kinetic energy variation with the injection velocity of the collecting device for $V_{m} / V_{s}=20$. (a) Behind the mining device, (b) Above the mining device, (c) Side of the mining device 

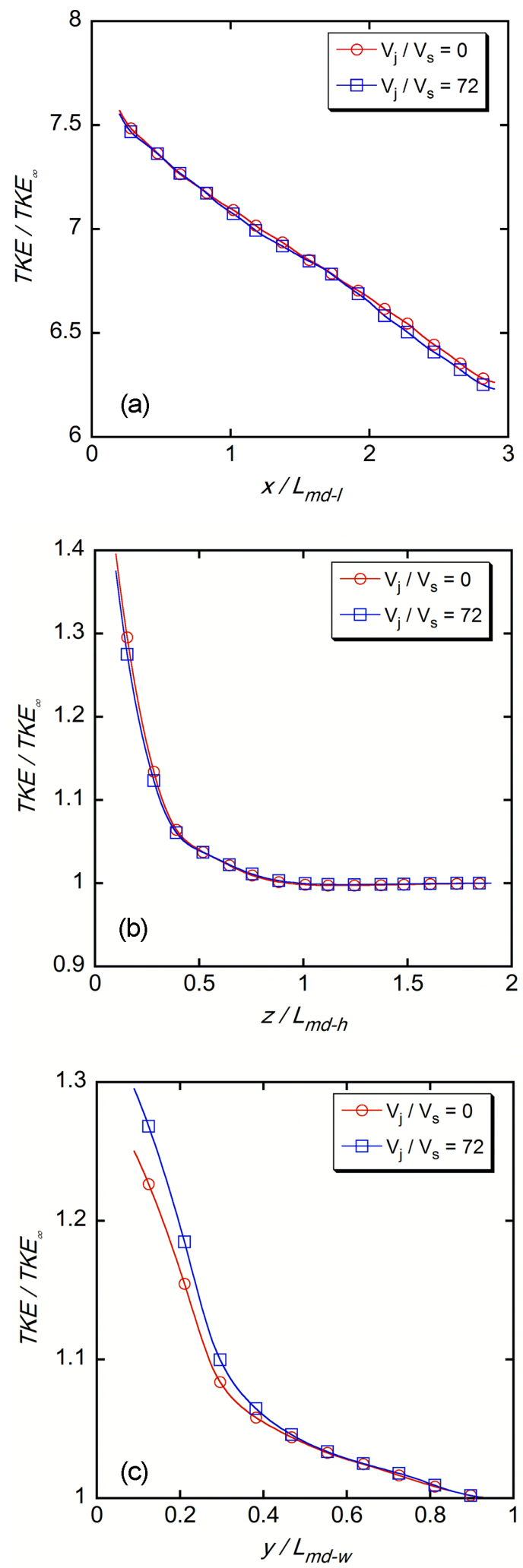

Fig. 12. Effect of injection velocity on averaged turbulent kinetic energy variation. (a) Behind the mining device, (b) Above the mining device, (c) Side of the mining device
것을 예측할 수 있다. 또한 $V_{m} / V_{s}$ 가 5만큼 증가할 때마다 집광기가 영향을 미치는 범위 내에서의 평균 난류운동에 너지는 약 $1 \%$ 증가하는 것을 볼 수 있다. (c)는 집광기 옆 쪽에서의 평균 난류운동에너지 변화를 나타낸 것이다. 옆 쪽에서의 평균 난류운동에너지는 집광기에 의한 영향을 받지 않는 영역의 난류운동에너지에 비해 최대 약 1.3 배 정도 높게 나타나고 $L_{m d-w}$ 의 약 0.3 배 영역까지 급격하게 감소한 후 0.9 배 정도 되는 영역까지 서서히 감소하여 이 후부터 집광기에 의한 영향이 없어지는 것으로 예측된다. 또한 $V_{m} / V_{s}$ 가 5만큼 증가할 때마다 집광기가 영향을 미치 는 범위 내에서의 평균 난류운동에너지는 약 $0.5 \%$ 증가하 는 것을 볼 수 있다. Fig. 11은 $V_{j}$ 변화에 따른 난류운동에 너지변화를 나타낸 것이다. (a) (c)에서 나타난 것과 같이 뒤, 위, 그리고 옆 방향으로 $V_{j}$ 변화에 따른 난류운동에너 지의 변화가 별로 크지 않은 것을 볼 수 있다. 이는 채집 장치로부터 분사되는 제트류의 분사속도 대비 흡입부의 흡입 압력이 높기 때문에 제트류 분사가 되었을 경우 주 변 해수유동에 영향을 주기 전에 흡입부로 해수가 흡입되 어지는 것으로 판단된다. Fig. 12는 채집장치의 작동 유/ 무에 따른 평균난류운동에너지의 차이를 나타낸 것이다. 채집장치가 작동되면 제트류 분사장치 및 망간단괴 흡입 장치가 작동하게 되는데 이때 제트류 분사장치와 망간단 괴 흡입장치가 작동되는 경우와 작동하지 않는 경우의 집 광기 주변 난류운동에너지 변화를 (a) (c)에 나타낸 것이 다. 채집장치 작동 유/무에 따른 평균 난류운동에너지는 집광기 뒤쪽과 위쪽 방향으로는 거의 차이가 없는 것을 볼 수 있다. 반면에 옆쪽에서는 채집장치 작동 시 집광기 가 영향을 미치는 범위 내에서의 평균 난류운동에너지가 약 $1.4 \%$ 정도 증가하는 것을 볼 수 있다. 이는 채집장치 가 구조상 집광기 전방 하단에 장착되어 있기 때문에 $V_{j}$ 의 초기속도가 집광기 뒤쪽과 위쪽까지 영향을 미치지 못하 여 옆쪽에만 영향을 미치는 것으로 판단된다.

\section{망간단괴의 거동 예측}

Fig. 13의 (a) (c)는 해저면 망간단괴의 거동을 시간 변 화에 따라 비정상상태로 해석하여 예측한 것이다. 대부분 의 입자는 채집장치 흡입부로 흡입되지만 일부 입자는 흡 입되지 않고 해수유동을 따라 집광기의 옆쪽 및 하단 부 의 캐터필러 사이를 통해 점차 뒤쪽으로 이동하게 된다. 이때 집광기 뒤쪽으로 이동하게 된 입자는 와류에 의한 복잡한 형태의 해수유동을 따라 불규칙한 거동 특성이 나 타나게 된다. Fig. 14는 해저면 망간단괴의 거동이 난류운 동에너지에 미치는 영향을 시간 변화에 따라 비교한 것이 다. (a)는 집광기 뒤쪽에서의 난류운동에너지 변화를 나타 낸 것인데 망간단괴가 있는 경우가 없는 경우보다 난류운 동에너지가 더 큰 것을 볼 수 있다. 또한 입자가 있는 조 


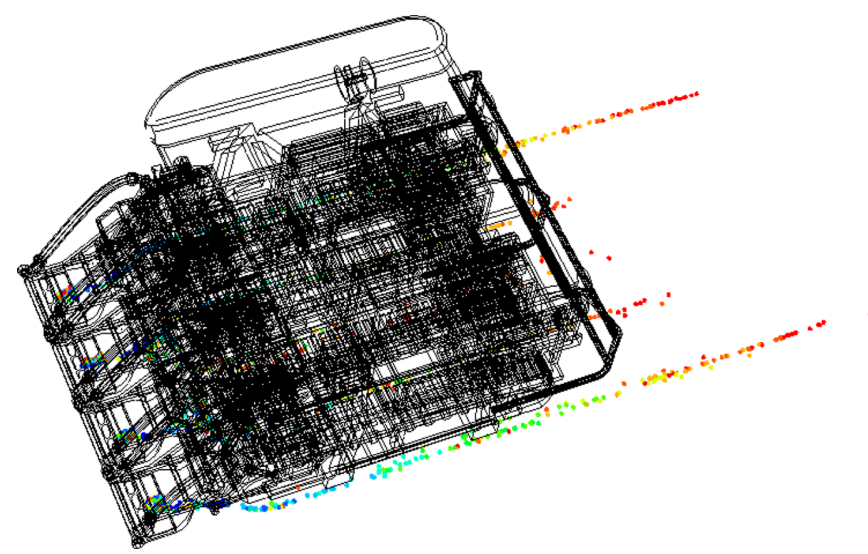

(a) $10 \mathrm{sec}$

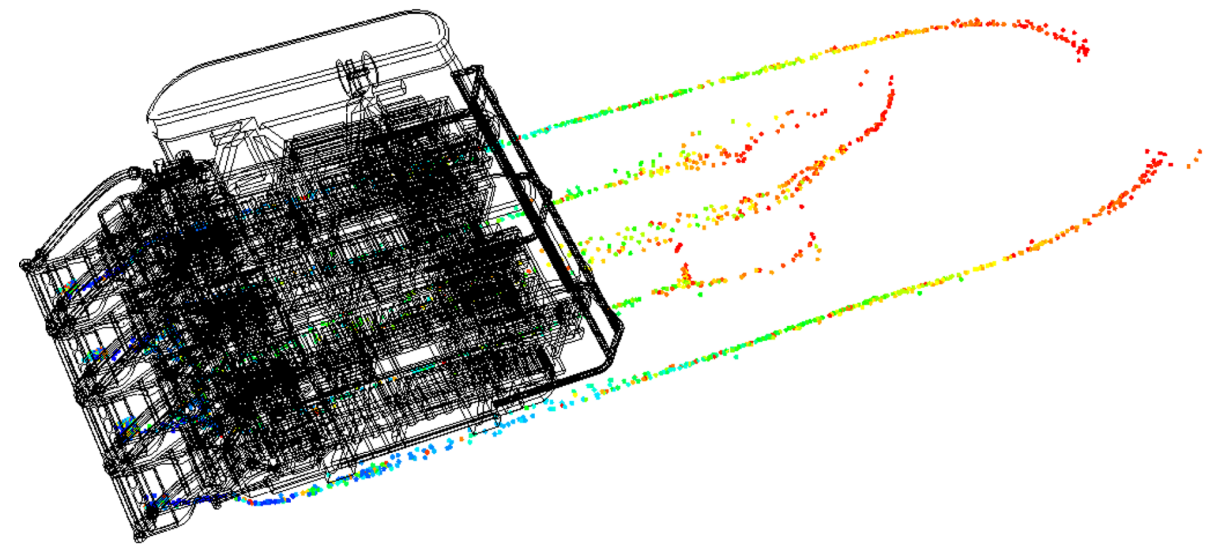

(b) $20 \mathrm{sec}$

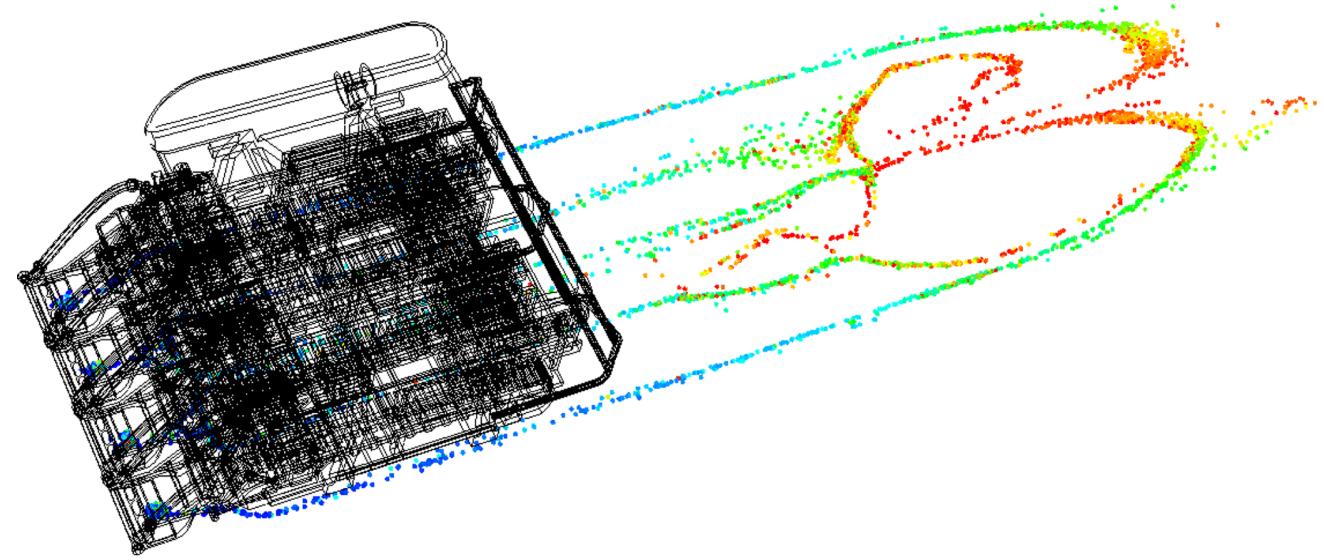

(c) $30 \mathrm{sec}$

Fig. 13. Transient behavior of manganese nodules near the mining device

건에 대하여 시간 변화에 따른 난류운동에너지의 변화는 거의 없는 것을 볼 수 있는데 이는 분사장치의 제트류 분 사에 의한 입자의 초기 거동 속도가 집광기 뒤쪽으로 가 면서 점차 감소하여 뒤쪽에서는 입자가 낮은 속도로 거동 하여 해수유동에는 큰 영향을 미치지 않는 것으로 예측된
다. (b)는 집광기 위쪽에서의 난류운동에너지 변화를 나타 낸 것이다. 입자는 대부분 해저면을 따라 후방으로 거동하 기 때문에 집광기 위쪽에서는 입자에 의한 해수유동장의 변화가 거의 발생하지 않는 것으로 판단된다. (c)는 집광 기 옆쪽에서의 난류운동에너지 변화를 나타낸 것이다. 분 

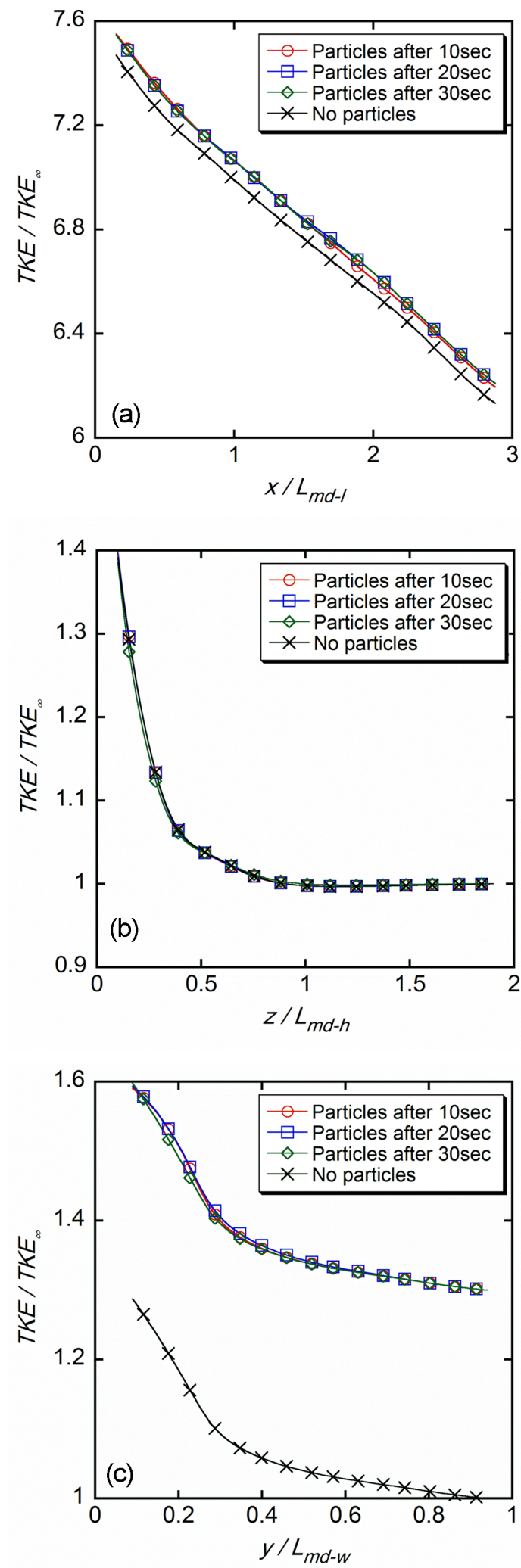

Fig. 14. Comparison of averaged turbulent kinetic energy variation with particles for various time. (a) Behind the mining device, (b) Above the mining device, (c) Side of the mining device
사장치의 제트류에 의해 입자가 초기 거동 속도에 비해 느려지지 않은 채로 옆쪽으로 빠르게 퍼져 나간 후 해수 유동을 따라 이동하는 특징을 나타내기 때문에 다른 영역 에 비해 옆쪽에서는 입자의 거동이 해수유동에 미치는 영 향이 비교적 많이 나타나고 이로 인해 시간 변화에 따른 난류운동에너지의 변화도 높게 나타난다.

\section{4. 결 론}

본 연구에서는 심해저 망간단괴 집광기 운행 시 주위의 해수유동장에 미치는 영향을 전산해석기법을 이용하여 분 석하였다. 이를 통해 집광기의 이동속도, 채집장치의 제트 류 분사속도, 채집장치의 작동, 그리고 해저면의 망간단괴 등 다양한 조건에서의 집광기 주변의 해수 유동교란 특성 변화를 파악하였다.

(1) 집광기 주변의 해수유동장은 집광기의 앞, 뒤, 위, 그리고 옆의 각 방향에서 서로 다른 해수유속 분포의 변 화 특성이 나타났다. 집광기 전방으로부터 흐르는 해수는 집광기 앞쪽에서 유속이 줄어들기 시작하여 뒤쪽으로 가 면서 유동박리 현상과 함께 와류가 발생하여 유속이 $0 \mathrm{~m} / \mathrm{s}$ 에 가까운 후류영역이 나타나게 된다. 이에 따라 집광기 뒤쪽에서는 와류 현상과 함께 상당한 난류운동에너지가 발생하게 되는데 집광기에 의해 영향을 받지 않는 영역의 난류운동에너지에 비해서 약 8 배 정도까지 난류운동에너 지가 크게 증가하게 된다.

(2) 집광기로부터 후방으로 멀어질수록 난류운동에너지 는 점차 감소하게 되고 집광기 옆쪽에서는 집광기 폭의 약 0.9 배 정도, 위쪽에서는 집광기 높이의 약 1.8 배 정도 까지 난류운동에너지의 분포 변화가 발생한다. 이러한 난 류운동에너지의 분포변화특성을 통해 심해저에서의 집광 기 운행에 따른 영향이 미치는 거리를 파악할 수 있다.

(3) 집광기의 이동속도 $V_{m} / V_{s}$ 가 5 만큼 증가할 때 집광기 가 영향을 미치는 범위 내에서의 난류운동에너지는 집광 기의 뒤쪽, 옆쪽, 위쪽에서 각각 약 $4 \%, 0.5 \%, 1 \%$ 정도로 증가하게 된다. 이와 함께 채집장치 작동 유/무에 따른 집 광기 주변 평균 난류운동에너지는 집광기의 뒤쪽, 위쪽에 서는 별 다른 변화가 없었지만 옆쪽에서는 약 $1.4 \%$ 정도 의 차이가 발생하였다.

(4) 집광기 운행 시 망간단괴의 거동이 해수유동에 영향 을 미치게 되어 비교적 큰 난류운동에너지가 발생하였다. 특히 집광기 옆쪽에서 망간단괴 거동에 따른 해수유동의 큰 변화가 나타났다.

본 연구의 결과는 망간단괴의 채집과정에서 발생되는 복잡한 해수유동 특성과 관련된 집광기의 구조적인 설계 및 작동조건의 최적화에 도움이 될 것으로 기대되며 차후 실험데이터와의 비교 및 분석이 필요할 것으로 판단된다. 


\section{사 사}

본 연구는 해양수산부 R\&D 사업인 태평양 심해저 광 물자원 개발(PM57950)의 지원으로 수행되었습니다. 연구 지원에 감사드립니다.

\section{참고문헌}

이민욱, 홍섭, 최종수, 김형우, 여태경, 민천홍, 조수길, 이태 희 (2013) 코안다 효과를 이용한 심해저 망간단괴 유체식 채집장치 최적설계. In: 대한기계학회 추계학술대회, $\mathrm{pp}$ $1660-1665$

이진우, 최영도, 윤치호, 박종명, 이영호 (2009) 심해저 양광 시스템용 사류펌프의 내부유동해석. In: 한국동력기계공 학회 학술대회 논문집, pp 104-107

조수길, 이민욱, 임우철, 최종수, 김형우, 이창호, 홍섭, 이태 희 (2012) 심해 잡음인자를 고려한 망간단괴 시험 집광기 의 채집운용시 주행장치 다구치 강건설계. 한국해양공학 회지 26(1):41-46

최종수, 여태경, 김형우, 박성재, 윤석민, 홍섭 (2010) 심해저 망간단괴 시험집광기의 근해역 집광성능 분석. Ocean and Polar Res 32(4):463-473

김종원, 이상호 (2013) 쉬라우드 형상 별 조류발전 터빈 주위 의 해수유동특성. 한국기계기술학회지 12:390-399

최종수, 이태희, 홍섭, 심재용 (1998) 심해저 망간단괴 집광기 채집장치의 설계평가. 한국정밀공학회지 15(3):11-168

김형우, 홍섭, 이창호, 최종수, 여태경 (2010) 심해저 광물자 원 채광시스템의 통합거동 해석. 한국항해항만학회지 34(3):195-203

변성준, Stephane C, 김석원, 권혁빈 (2014) LBM 기법을 이 용한 고속열차 공기저항 전산해석. In: 한국철도학회 학 술발표대회논문집, pp 1660-1665

Yoon C-H, Kang J-S, Park J-M, Park Y-C, Kim Y-J, Kwon S-K (2009) Flow analysis by CFD model of lifting system for shallow sea test. In: Proceedings of the isope ocean mining \& gas hydrates symposium, pp 225

Aljure DE, Lehmkuhl O, Rodriquez I, Oliva A (2014) Flow and turbulent structures around simplified car models. Comput Fluids 96:122-135

Boelens OJ (2012) CFD analysis of the flow around the X31 aircraft at high angle of attack. Aerosp Sci Technol 20(1):38-51

Rinoshika A, Watanabe S (2010) Orthogonal wavelet decomposition of turbulent structures behind a vehicle external mirror. Experimental Thermal and Fluid Sci 34:13891397
LRET Collegium (2012) Feasibility study on manganese Nodules Recovery in the Clarion-Clipperton Zone. The LRET Collegium 2012 Series, University of Southampton, UK, $132 \mathrm{p}$

\section{국문 참고자료의 영어 표기}

English translation / Romanization of references originally written in Korean

Lee M-U, Hong S, Choi J-S, Kim H-W, Yeu T-K, Min C-H, Cho S-G, Lee T-H (2013) Design optimization of a hydraulic deep-sea manganese pick-up device using Coanda effect. In: Proceedings of the KSME fall annual meeting, pp 1660-1665 (in Korean)

Lee J-W, Choi Y-D, Yoon C-H, Park J-M, Lee Y-H (2009) Internal flow analysis on a mixed flow pump for deepsea mineral lifting system. Korea Soc Power Sys Eng 6:104-107 (in Korean)

Cho S-G, Lee M-U, Lim W-C, Choi J-S (2012) Taguchi robust design of tracked vehicle for manganese nodule test miner in collecting operation considering deep-sea noise factors. J Ocean Eng Technol 26(1):41-46 (in Korean)

Choi J-S, Yeu T-K, Kim H-W, Park S-J, Yoon S-M, H S (2010) Performance analysis of deep sea manganese nodule rest miner in inshore tests. Ocean and Polar Res 32(4):463-473 (in Korean)

Kim J-W, Lee S-H (2013) Seawater flow characteristics around tidal current power turbine for various shroud. J Korean Soc Mech Technol 12:390-399 (in Korean)

Choi J-S, Lee T-H, H S, Sim J-Y (1998) Design evaluation of pickup device collecting deep-sea manganese nodules. J Korean Soc Prec Eng 15(3):11-168 (in Korean)

Kim H-W, H S, Lee C-H, Choi J-S, Yeu T-K (2010) Total dynamic analysis of deep-seabed integrated mining system. J Korean Nav Port Res 34(3):195-203 (in Korean)

Byun S-J, Stephane C, Kim S-W, Kwon H-B (2014) Numerical simulation of aerodynamic drag for highspeed train using LBM. In: Proceedings of the KSR conference, pp 1660-1665 (in Korean)

Received Oct. 21, 2014

Revised Nov. 18, 2014

Accepted Dec. 16, 2014 